GOSPODARKA SUROWCAMI MINERALNYMI - MINERAL RESOURCES MANAGEMENT

\title{
Forecasting the price of uranium based on the costs of uranium deposits exploitation
}

\section{Introduction}

It is expected that the worldwide electricity consumption will continue to grow with the growing population. Forecasts of electricity consumption - differing from each other only with respect to the growth rate of electricity consumption - are published each year by a number of organizations. Each of them takes the growing share of nuclear power into account, which in recent years is experiencing a renaissance, although the enthusiasm to build new reactors has faded since the 2011 Fukushima disaster (Dittmar 2013). Still, many countries have ambitious plans for the future to increase the installed capacity of nuclear power (Gabriel et al 2013; Strategic... 2010). This is the result of several overlapping factors favoring the development of nuclear power, among which following should be mentioned (Halland and Coleman 2013):

- The need to reduce greenhouse gas emissions.

- The expected increase in fossil fuel prices.

- The need to meet the rapidly growing energy demand in developing countries such as China and India.

- The increased pressure to ensure energy security in the context of the possible depletion of supplies of fossil fuels.

* PhD. Eng., ** D.Sc, Eng., Mineral and Energy Economy Research Institute, PAS, Krakow, Poland; e-mail: kryzia@min-pan.krakow.pl; lidia.gawlik@min-pan.krakow.pl 
It should be remembered that nuclear power is the largest, after hydropower, worldwide energy source with low carbon dioxide emissions (Cole 2015; BP Statistical 2016). The further development of nuclear energy can facilitate the implementation of programs for the protection of the environment and improve energy security. The fact that nuclear fuel prices have no significant impact on the costs of power generation in nuclear power plants is also of great importance. Even much higher uranium prices will not affect the competitiveness of nuclear power compared to other sources based on fossil fuels, as the costs of uranium it is about $3-5 \%$ of the cost of electricity production in nuclear power plants (Mays 2005; Cole 2015). In the case of coal fired power plants, these costs account for around $75 \%$ (Cole 2015). In the case of nuclear power plants, the highest share in the levelized cost of energy production (LCOE) is observed for costs resulting from capital expenditures (Kahouli 2011a).

Currently, the electricity production based on the use of fissile material plays an important role in the energy balance of thirty countries, of which 13 countries generate more than a quarter of the electricity in the nuclear power plants (Cole 2015).

Despite many advantages of nuclear power, a number of challenges and uncertainties, including in particular the unresolved question of storage and disposal of nuclear waste, public concerns about the safety of nuclear energy and high investment costs associated with the construction of power plants, affecting the economic efficiency of projects of this type, should be expected. This limits or even prevents the development of nuclear power in many countries (Kahouli 2011a; Hall and Coleman 2013).

In 2014 Poland adopted a nuclear power development plan (PPEJ 2014) and plans to build and run the first power unit using the process of nuclear fission in the future. The implementation of these plans raises a lot of controversies concerning, among others, the economic efficiency of the project and its impact on electricity prices for consumers. Many researchers have tried to estimate the economic effect of the investment involving the construction and launching of a nuclear power plant in Poland. This research was also conducted in the MEERI PAS (Gawlik ed. 2013). The above mentioned studies required the estimation of future cash flows generated by the project throughout its life cycle, including the construction, operation and decommissioning a generating unit. These flows consist of income and expenses. One category of costs is the cost of nuclear fuel, taking the costs of the uranium ore, its processing into uranium hexafluoride gas, its enrichment in the U235 isotope, and the production costs of fuel elements into account (Nuclear... 2009). The most important is the cost of natural uranium. Therefore, it is important to estimate the future uranium prices, as they are essential for the construction of the project cash flows. For this purpose, forecasts prepared by various academic, governmental, and non-governmental institutions and organizations, occasionally publishing documents containing uranium price forecasts, are typically used. However, they typically cover a relatively short time span, usually up to several years. This is due to large uncertainties related to long-term price forecasts. In the case of nuclear energy, with the estimated lifespan of power units at around 60 years, the available forecasts of uranium prices are insufficient, as they do not cover the not-so-distant 
future. A typical solution used in such cases is the extrapolation of prices for the coming years. However, this method is not always possible or effective. In such cases, developing own forecast or commissioning it from external institution is usually necessary. The MEERI PAS team has faced this need due to the lack of appropriate long-term forecasts of uranium prices and has prepared the forecast based on own-developed method, which - in a slightly modified form - is presented in this paper.

\section{The model}

The existing literature on the formation of uranium prices is mainly focused on models for estimating the demand and supply (Cole 2015). However, there have been only a few works on this issue despite the fact that the stability of the uranium market is a key factor in the successful expansion of nuclear power. The most important papers on the empirical analysis of issues related to the supply and demand of uranium and on their relationship with the development of nuclear energy, include: Basheer Ahmed (1979), Owen (1984), Owen(1985), Trieuet al. (1994), Amavilah(1994), Amavilah (1995), IAEA (2001) and Kahouli (2011b).

In this paper, based on the results of previous studies in this field, the forecasting of uranium prices was done using the market balance equation defining mutual dependencies between the demand size, supply size and the price level of raw material. The law of supply and demand assumes that when supply and demand are equal, the market equilibrium price level can be specified. Thus, the market price of uranium is an important barometer of the perceived balance between supply and demand for uranium. Increases in market prices suggest a potential or alleged shortage of supply while this may stimulate supply growth. In contrast, price drop indicates the actual or perceived excess supply (NEA 2006).

The current market price of uranium is largely a consequence of the balance between supply and demand for this raw material. However, it has not always been like that. Until the end of the Cold War, the military demand for uranium was affecting the market of this raw material due to security requirements and military secrecy. After 1989, uranium prices gradually prices started to behave like the prices of other typical commodities, though the supply coming from the dismantling of nuclear warheads, now used for civilian applications, still had a significant impact on the market of this raw material, including the balance between supply and demand. Among others, this is the reason why today's uranium market is a bit different than the markets of other raw materials. In addition, today's uranium market, although more liquid than in the past, is still less liquid than the markets for other raw materials and fuels. This is an important feature, because - according to the theory of market equilibrium - a high degree of market liquidity is desired. This issue was discussed by UPA (2015).

A distinctive feature of this market is the dominance of long-term contracts, accounting for about $90 \%$ of uranium trade. Meanwhile, the spot market accounts for only $10 \%$ of ura- 
nium trade. It is estimated that the total annual amount of contracted uranium in the world (including spot transactions and long-term contracts) rarely exceeded 68 thousand $\mathrm{Mg}$.

The most important feature of this market, however, is its independence from other commodity markets (NEA 2006). The existing empirical studies of the uranium market (Basheer Ahmed 1979; Amavilah 1994; Amavilah 1995) have shown that uranium prices change regardless of the price of competing fossil fuels, such as coal and oil, despite the fact that Newcomb and Reiber (1984) provided a solid theoretical foundation for the existence of certain significant relationships between the prices of uranium and the prices of other fuels. This hypothesis was verified by Kahouli (2011b), who has focused on the relationship between the prices of uranium, competing fuels and other metals such as gold, copper, and silver. The research results, in contrast to previous studies, suggest that uranium prices are related to coal (considered as a substitution fuel). This relationship, although statistically significant, is relatively weak, and therefore its importance in shaping the price of uranium is low. Hence, it can be assumed that the price of uranium will be shaped by (Cole 2015; Kahouli 2011b):

- The demand, which is almost completely dependent on the installed capacity of nuclear power units operating as base load units. Uranium is also used to produce medical radioisotopes and military equipment, though in small amounts (Amavilah 1994; Trieuet et al. 1994; Amavilah 1995; Maeda 2005; NEA 2006; Kahouli 2011b).

- The primary and secondary supply. The primary source of uranium is naturally occurring uranium in the currently exploited uranium deposits. In the event when the supply from primary sources is not sufficient, the deficit is balanced by uranium derived from secondary sources, which in 2014 secured approximately $19 \%$ of the market demand for uranium (UPA 2015). This category includes: stocks of enriched and natural uranium from civilian and military sources, uranium recycled from spent fuel, and highly enriched uranium recovered from dismantled nuclear warheads and converted to low enriched uranium (McMurray 2005; Strategic... 2010; Kahouli 2011a; Dittmar 2013; Gabriel et al. 2013).

\subsection{The demand}

According to the law of demand, it is expected that the demand for uranium will react to changing prices of this raw material - any increase (decrease) in the price will result in a decrease (increase) in demand. The results of the majority of previous studies, however, suggest that the demand for uranium is insensitive to price fluctuations and is not related to the projected prices (Patterson 1970; Thomas 1984; Owen 1984; Owen 1985; OECD/NEA 1987; Amavilah 1994; Amavilah 1995). This very low price elasticity results from the operation mode of nuclear power plants, generating energy continuously and with almost constant power, since these are usually base load units. The second factor is the time-consuming construction of expensive nuclear power plants. 
In this aspect, the uranium market is different when compared to other commodity markets. However, subsequent studies have confirmed that there is no significant correlation between the demand and the price of uranium in the short term (Kahouli 2011b). In the long term, however, there is a statistically low correlation between the uranium prices and demand for this raw material, while the reaction of demand to changes in raw material prices is a (slow) process in time (OECD/NEA 2008; Kahouli 2011a, 2011b).

In addition, it has been shown that the demand for uranium is insensitive to fluctuations in uranium and other fossil fuel prices (Basheer Ahmed 1979; Amavilah 1994, 1995; Kahouli 2011a, 2011b).

\subsection{The supply}

According to the law of supply, an increase in the price of uranium encourages the search for uranium and its production. The price of uranium is the most important factor determining the development of new mining projects (Mays 2005; Kahouli 2011b).

The elasticity of uranium supply prices is very low due to the limited production capacities of mines and the capital-intensive, time-consuming, and risk-laden investment process aimed at increasing the production in mines being the main source of uranium in the market (Layton 2008). At the same time the supply of this raw material from secondary sources, although more flexible, is uncertain and limited (Gabriel et al. 2013). This is the reason why the response of manufacturers to price volatility is not immediate. For example, in 1973 uranium prices increased significantly but the increase in uranium production started only in 1975. A similar situation took place in the 1980s when a decrease in the uranium production occurred only seven years after a drop in prices (Kahouli 2011a).

\subsection{The resources}

Estimating the future costs of uranium mining, determining the price of this raw material, requires knowledge of uranium resources. Since the mid-sixties, the Nuclear Energy Agency of the OECD (OECD/NEA) and the International Atomic Energy Agency (IAEA) regularly publish a report, commonly known as the Red Book, summarizing the current state of research, resources (deposits), and uranium production, along with the demand of nuclear power plants for this raw material. Moreover, official data on this topic is available on government websites of some countries (e.g. The United States, Canada). In addition, some mining groups provide this information as part of their financial reporting.

Australia has the world's largest resources of uranium, followed by Kazakhstan and Canada. In 2012, the world production of natural uranium amounted to 58800 tons, of which 
$36 \%$ were produced in Kazakhstan, $15 \%$ in Canada, and a little more than $12 \%$ in Australia (OECD/NEA 2015).

Uranium is currently produced exclusively from conventional sources, although there are many unconventional uranium resources, among which sea water and phosphates deposits are the most prospective. Unconventional uranium resources are less reliable due to their limited availability and possibility of recovery (exploitation) (Gabriel et al. 2013).

Uranium production gradually reduces the known resource base of this material. Replenishing the resource base requires conducting continuous research. Despite many years of exploration, large areas are still to be examined using modern techniques. Increased exploration activity using new deposit models and exploration techniques makes it possible to increase the known uranium resources. Some countries, such as Australia, Gabon, and Namibia, have more potential for the discovery of deposits in poorly identified areas (NEA 2006; Gabriel et al. 2013).

The increase in uranium prices is beneficial for the exploration of uranium deposits. Thus, the price of uranium indirectly affects the size of the resource base by shaping expenditures incurred on the exploration, which is reflected in the number of exploration boreholes. This, in turn, is positively correlated with the size of the newly discovered uranium deposits. Changing the amount of expenditures on exploration is delayed with respect to changes in market prices because it takes time to see whether the new price level is durable. In addition, planning exploration activities and preparing the necessary documentation is also time-consuming. Therefore, the increase in the resource base usually reflects the increase in expenditures on exploration activities incurred several years earlier. With time, this period will be longer and longer because the prospective resources of the discussed raw material are located deeper, which makes it increasingly difficult to explore them. This requires more innovative techniques of exploration, more time, and drilling work generating higher costs (NEA 2006; Gabriel et al. 2013; Hall and Coleman 2013). There is evidence of a significant correlation between expenditures on uranium exploration and the supply of this raw material (Greenwood 1981). The supply response to the increase in expenditures on exploration is slow because the opening of a mine requires time associated with the process of granting licenses and construction of the mine infrastructure. It is estimated that it currently takes from 15 to 20 years from the discovery of a deposit to the start of mining activities (Hall and Coleman 2013).

\subsection{The price}

The three main factors determining the price of uranium are: the uranium supply, expected future uranium prices, and the prices of competing fossil fuels, mainly oil and coal (Kahouli 2011b). In addition, some authors point to the amount of uranium resources (Basheer Ahmed 1979).

The sensitivity of uranium prices to changes in the supply is a natural phenomenon resulting from the law of supply. The results presented by Kahouli (2011b) suggest that an 
increase in uranium supply by $1 \%$ would result in a decrease in the uranium prices by approximately $0.61 \%$.

Numerous studies confirm that there is a correlation between the prices of competing fossil fuels and uranium, though this correlation is weak (Amavilah 1994, 1995; Kahouli 2011b).

The study by Kahouli (2011b) partially confirms the results presented by Amavilah (1995) and Crowson (2007) suggesting that the expected future prices of uranium are putting pressure on uranium prices and therefore are essential for shaping the price of this raw material under the current market conditions. However, this effect was not as important as reported by Crowson (2007). The reaction of uranium prices to these factors is inelastic in the short term with the exception of a response to changes in coal prices. However, in the long term, uranium prices respond to the changing values of the aforementioned factors.

It should be noted that the limited response of uranium prices to changing amount of electricity produced from nuclear energy and to the evolution of the installed capacities of nuclear power (although both of these parameters are shaping the demand for uranium) is counterintuitive and contradicts previous findings by Basheer Ahmed (1979).

\section{Assumptions}

A model for estimating the costs of uranium extraction over time, depending on the supply level sufficient to meet the demand from nuclear power plants, has been developed. The aforementioned costs, given the inelastic demand for uranium, determine the price of this raw material. This allows for estimating the future price of uranium on the basis of knowledge of the resource base and the relationships determining changes in parameters characterizing the resources.

In order to estimate the future uranium prices it is necessary to adopt a series of input data, assumptions, and limitations determining the shape of the model. The following are the most important ones.

1. Several prospective studies have shown that the worldwide installed capacity of nuclear power will increase significantly over the next few years. As a result, it is expected that the demand for uranium in this period will also significantly increase due to the fact that the increased use of MOX (Mixed Oxide Fuel - is nuclear fuel that contains more than one oxide of fissile material, usually consisting of plutonium blended with natural uranium, reprocessed uranium, or depleted uranium) and RepU (Reprocessed Uranium - is the uranium recovered from nuclear reprocessing, as done commercially in France, the UK and Japan and by nuclear weapons states' military plutonium production programs) fuels and the development of generation IV reactors, characterized by lower demand for fuel, will only be possible in the distant future (Kahouli 2011b; Hall and Coleman 2013). Due to the fact that the installed capacity of nuclear power in a given country depends on its economic efficiency, which is unpredictable and depends on laws and regulations 
that can be changed (Hall and Coleman 2013), the future demand for uranium is difficult to predict. Therefore, the presented paper assumed that the demand is stochastic and, based on the available forecasts, the future demand for uranium is presented in the form of probability distributions. The shape of the probability distribution should reflect the variability and the risk level of the explanatory variable. However, the results obtained by Clarke and Low (1993) and Geiger (2011) suggest that the choice of probability distributions for individual variables used in the Monte Carlo simulation has little effect on the final results. In addition, the authors' experience suggests that the shape of the probability distribution is of less importance when a sufficiently large number of simulation runs is carried out. In practice, it is often assumed that random variables have a triangular distribution, described by simple analytical dependencies, understandable for practitioners. The simplified description of stochastic variables is widely used, since it facilitates the calculations (Hammond 2000). To unambiguously determine the shape of the density function of triangular distribution, it is necessary to determine the three random variables, i.e.: the minimum, maximum, and most likely random variable. According to Johnson (1997) the beta-PERT distribution is an alternative to a triangular distribution, which better reflects the natural phenomena. The beta-PERT distribution is a modification of the beta distribution and is used when the number of available data is limited. In order to determine the distribution, it is necessary to provide, the minimum, maximum, and most likely random variables, as in the case of a triangular distribution (Jaśkowski 2015; Walczak 2015). In this paper, the random variables were described using the probability distributions presented above. The beta-PERT probability distributions of the global demand for uranium, shown in Table 1, were determined by an expert method using the forecasts of the world demand for uranium available in the literature.

Table 1. The parameters of probability distributions of the global demand for uranium [thousand $\mathrm{Mg}$ ]

Tabela 1. Parametry rozkładów prawdopodobieństwa wartości globalnego popytu na uran [tys. Mg]

\begin{tabular}{|c|c|c|c|}
\hline Year & The minimum value & The expected value & The maximum value \\
\hline 2016 & 68.0 & 75.2 & 82.4 \\
\hline 2020 & 70.8 & 84.6 & 98.4 \\
\hline 2025 & 75.1 & 97.3 & 119.5 \\
\hline 2030 & 77.1 & 107.7 & 138.3 \\
\hline 2035 & 78.0 & 117.0 & 156.0 \\
\hline 2040 & 78.2 & 125.6 & 173.0 \\
\hline 2045 & 76.9 & 133.0 & 189.1 \\
\hline 2050 & 74.5 & 139.3 & 204.1 \\
\hline
\end{tabular}

Source: own study based on: Hall and Coleman (2013), Metal... (2013), OECD/NEA (2015) 
2. Uranium Resources presented in the Red Book are divided into separate categories depending on the degree of deposit exploration. The possibility to use these resources is determined by their extraction costs. A summary of the available uranium resources, broken down by production costs, is presented in Table 2 . There are legitimate concerns about the reliability and accuracy of the data on uranium resources presented in the Red Book. They result from differences between countries when it comes to the assumed prices, costs, geological models, and rules of conducting audits during the prospecting and exploration of deposits (Mudd 2014). Moreover, the deposit structure is determined on the basis of a relatively small amount of data resulting from exploration activities. Therefore, the estimated size of resources in a given deposit is usually affected by considerable uncertainty resulting from limitations in deposit exploration (Nieć et al. 2012). For this reason, the analysis assumes that the uranium resources must be treated as a stochastic variable described with probability distributions, whose parameters, presented in Table 3, were determined by an expert method on the basis of the maximum possible resource estimation errors according to Nieć et al. (2012).

Table 2. Uranium resources in the explored deposits depending on the cost of extraction

Tabela 2. Wielkość zasobów złóż rozpoznanych w zależności od kosztu wydobycia

\begin{tabular}{|c|c|}
\hline $\begin{array}{c}\text { Production costs } \\
\text { [USD/kg U] }\end{array}$ & $\begin{array}{c}\text { Uranium resources in 2013 } \\
\text { [thousand Mg] }\end{array}$ \\
\hline$<40$ & 682.9 \\
\hline$<80$ & 1956.7 \\
\hline$<130$ & 5902.9 \\
\hline$<260$ & 7635.2 \\
\hline
\end{tabular}

Source: OECD/NEA (2015)

Table 3. The distribution of deviation values for the explored uranium deposits

Tabela 3. Parametry rozkładu odchylenia wartości rozpoznanych zasobów złóż

\begin{tabular}{|l|c|c|}
\hline \multicolumn{1}{|c|}{ Variable } & Unit & $\begin{array}{c}\text { Deviation values for the explored } \\
\text { uranium deposits }\end{array}$ \\
\hline Type of distribution & - & triangle \\
\hline The minimum value & $\mathrm{pp}$ & -15 \\
\hline The expected value & $\mathrm{pp}$ & 0 \\
\hline The maximum value & $\mathrm{pp}$ & 15 \\
\hline
\end{tabular}

Source: own study based on Nieć et al. (2012) 
3. The amount of uranium deposits for the estimation of indirect production costs was calculated using nonlinear interpolation on the basis of the data presented in the Red Book.

4. The prognosticated and speculative resources shown in the Red Book are based on indirect evidence and geological extrapolations. Both categories of resources are estimated and require substantial and further exploration work before they can be reclassified as the demonstrated resources (NEA 2006).

5. The progressive depletion of uranium deposits is the reason for a gradual increase in exploitation costs. This is due to the natural tendency to favor deposits with the lowest extraction costs. However, the actual production in deposits with low extraction costs is, for different reason, delayed or limited, forcing the exploitation of deposits with higher extraction costs, even though the former are not yet depleted (Mercure and Salas 2012, 2013).

6. The discovery of new uranium deposits, which will increase the resource base of this raw material, is possible. The price of uranium affects the expenditures incurred for the implementation of the exploration work, as described by the linear function. The size of the newly discovered uranium deposits, which increases the number of identified uranium deposits, depends on the expenditures for the implementation of exploration activities and the unit cost of the discovery of uranium deposits.

7. The period from the start of exploration to the discovery of new deposit usually takes several years. Once a deposit is discovered, it usually takes a few years before the deposit is explored and the process of resource estimation is completed (NEA 2006). For the purposes of this study it was assumed that a possible increase of the resource base will take place seven years after the start of exploration work.

8. Unit costs of the discovery of uranium deposits are affected by considerable uncertainty, and therefore are expressed in the form of a stochastic variable with distribution parameters shown in Table 4 . The expected value, which is a parameter of the triangular probability distribution, is equal to average unit costs of the discovery of uranium deposits presented in the NEA report (2006). This also applies to other parameters: the minimum and maximum values were determined on the basis of data from the same source.

Table 4. The distribution of unit costs of the discovery of uranium deposits

Tabela 4. Parametry rozkładu jednostkowych kosztów odkrycia złóż uranu

\begin{tabular}{|l|c|c|}
\hline \multicolumn{1}{|c|}{ Variable } & Unit & Unit costs of the discovery of uranium deposits \\
\hline Type of distribution & - & triangle \\
\hline The minimum value & \multirow{3}{*}{ USD/kg U } & 0.5 \\
\cline { 1 - 1 } & & 2.0 \\
\hline The expected value & & 5.0 \\
\hline The maximum value & &
\end{tabular}

Source: own study based on NEA (2006) 
9. The successive discoveries of new uranium deposits negatively affect the possibility of discovery of new uranium deposits in the future as their number is limited. Therefore, in terms of the more advanced exploration of uranium deposits, the unexplored area is getting smaller. Conducting exploration activities requires investment outlays. Therefore, cumulative value of expenditures incurred for exploration activities increases along with the increased exploration of uranium deposits. Therefore, it has been assumed that the probability of discovery of new uranium deposits decreases with the increasing cumulative value of expenditures incurred for exploration activities.

10. Uranium deposits discovered in a given year are characterized by different production costs. Their share in total resources discovered in a given year is random.

11. It has been assumed that the basis for the formation of uranium price in the market is the highest marginal cost of a single mine from the group of mines covering the total demand for uranium.

12. The structure of uranium production changes every year. The nature and pace of changes were determined on the basis of cost curves of uranium mining in 2013 and after 2020. These curves characterize the structure of uranium production in mines with different production costs (Metal... 2013).

13. The supply of uranium from secondary sources includes stocks of enriched and natural uranium from civilian and military sources, uranium recycled from spent fuel, and re -enriched uranium. However, its amount decreases each year. Despite the fact that the recycling of reprocessed uranium (RepU) and plutonium (MOX) will continue to play an important role in meeting the demand for nuclear fuel, it is expected that the downward trend will continue because of increasingly smaller stocks of military uranium (EURATOM 2013). The existing forecasts of uranium supply from secondary sour-

Table 5. The parameters of probability distributions of the secondary uranium supply [thousand $\mathrm{Mg}$ ]

Tabela 5. Parametry rozkładów prawdopodobieństwa wartości wtórnej podaży uranu [tys. Mg]

\begin{tabular}{|c|c|c|c|}
\hline Year & The minimum value & The expected value & The maximum value \\
\hline 2016 & 5.9 & 9.7 & 13.6 \\
\hline 2020 & 5.5 & 9.7 & 13.9 \\
\hline 2025 & 4.9 & 9.3 & 11.5 \\
\hline 2030 & 3.7 & 7.6 & 10.6 \\
\hline 2035 & 3.0 & 6.8 & 9.3 \\
\hline 2040 & 2.3 & 5.8 & 8.1 \\
\hline 2045 & 1.7 & 4.9 & 6.7 \\
\hline 2050 & 1.2 & 4.0 & 6.7 \\
\hline
\end{tabular}

Source: own study based on: AERA (2010), Metal... (2013), Nikolaus (2014) 
ces differ from each other. Sometimes the difference is significant and therefore, on the basis of literature data, the future demand for uranium is presented in the form of probability distributions (beta-PERT distributions). The parameters of the probability distribution shown in Table 5 were determined by an expert method using the forecasts of the secondary supply of uranium available in the literature.

14. The global demand for uranium in a given year and the previous year are mutually correlated. The coefficient of correlation is not known. Therefore, it is assumed as a random number described by the probability distribution with the parameters shown in Table 6 .

Table 6. Parameters of the distribution of the Spearman correlation coefficient

Tabela 6. Parametry rozkładu wartości współczynnika korelacji rang Spearmana

\begin{tabular}{|c|c|}
\hline Variable & The correlation coefficient \\
\hline Type of distribution & rectangular \\
\hline The minimum value & 0.4 \\
\hline The maximum value & 0.8 \\
\hline
\end{tabular}

Source: own study

15. Despite the fact that the impact of uranium stocks on the prices of this raw material can be statistically significant, this study does not take this relationship into account. This is due to the limited knowledge on the evolution of this relationship and its complexity.

16. The data on completed projects in the field of uranium mining carried out in different countries and regions show that - on average - only $50-70 \%$ of the initial resources of uranium is mined from the deposit (Dittmar 2013).

\section{Summary and conclusions}

The analysis of production costs of uranium from various deposits allowed the future price of uranium to be determined. On the basis of the Monte Carlo simulation, probability distribution of uranium prices in the coming years until 2050 has been obtained. The estimation of uranium prices is shown in Table 7 and Figure 1.

The forecast of uranium prices provides a basis for estimating future nuclear fuel prices.

The resulting price distributions are characterized by right-handed asymmetry, which means that the prices are more likely to increase than decrease.

According to the forecasts, uranium prices will be stable until the year 2030. In the coming years, a gradual increase in prices should be expected, while the pace of changes in the coming years is likely to accelerate. The presented forecast is of a long-term nature and 
Table 7. The forecast of uranium prices by $2050[\mathrm{USD} / \mathrm{kg} \mathrm{U}]$

Tabela 7. Prognoza cen uranu do $2050 \mathrm{roku}$ [USD/kg uranu]

\begin{tabular}{|l|r|r|r|r|r|c|c|}
\hline \multicolumn{1}{|c|}{ Year } & 2020 & 2025 & 2030 & 2035 & 2040 & 2045 & 2050 \\
\hline The expected value & 91 & 90 & 91 & 97 & 108 & 118 & 130 \\
\hline The value for the 10th percentile & 85 & 85 & 85 & 95 & 105 & 115 & 125 \\
\hline The value for the 90th percentile & 105 & 105 & 95 & 105 & 115 & 125 & 145 \\
\hline
\end{tabular}

Source: own study

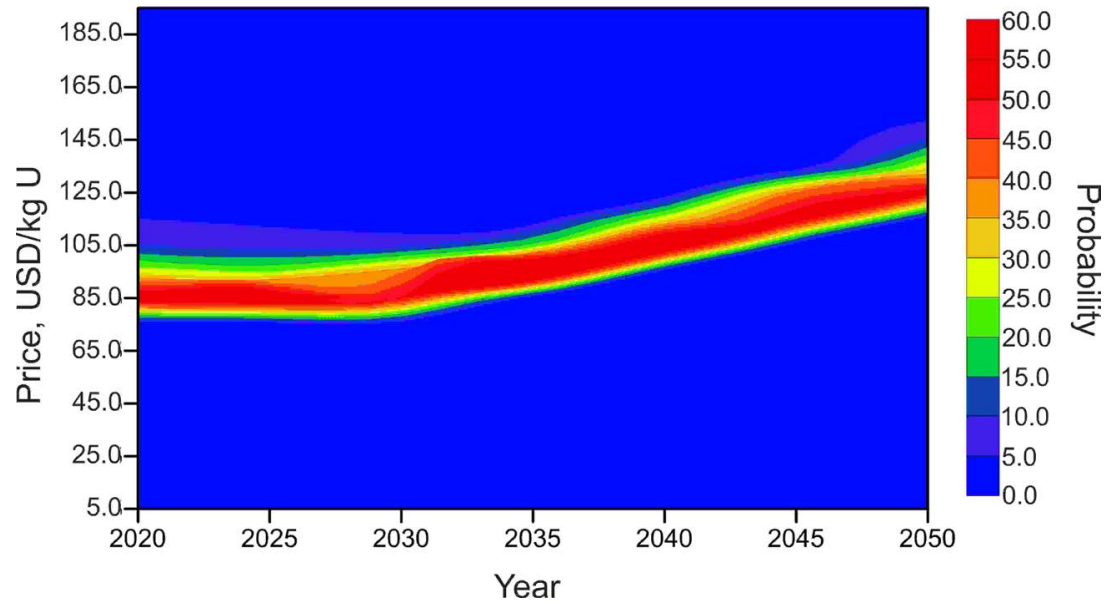

Fig. 1. Uranium prices and the probability of their occurrence Source: own study

Rys. 1. Ceny uranu wraz z prawdopodobieństwem ich wystąpienia

therefore does not take the extreme short-term fluctuations in prices, significantly exceeding the range presented in the forecast, that can occur, into account. They are driven by non-fundamental factors and therefore do not undermine the presented forecast, which is based on fundamental premises.

The model is most sensitive to the size of uranium deposits that are discovered every year and therefore it is important to closely match this element in the model. A characteristic feature of the model resulting from the adopted assumptions regarding the relationship between variables is the stability of forecasts of uranium prices and a small gap and standard deviation of prices calculated for individual years.

This study was done within the statutory research of the Mineral and Energy Economy Research Institute, Polish Academy of Sciences. 


\section{REFERENCES}

Amavilah, V.H.S. 1994. The influence of oil and coal prices on the world uranium demand. OPEC Review 18(4), pp. 489-508.

Amavilah, V.H.S. 1995. The capitalist world aggregate supply and demand model for natural uranium. Energy Economics $17(3)$, pp. 211-220.

AERA 2010. Basheer Ahmed, S. 1979. Nuclear Fuel and Energy Policy. Princeton University, Center of International Studies, Lexington, Massachusetts, Toronto.

BP Statistical 2016. BP Statistical Review of World Energy 2016. [Online] Available at: (www.bp.com/content/dam/bp/pdf/energy-economics/statistical-review-2016/bp-statistical-review-of-world -energy-2016-full-report.pdf) [Accessed: 1.08.2016].

Clarke, R. and Low, A. 1993. Risk Analysis in Project Planning: A Simple Spread-sheet Application using Monte Carlo Techniques. Project Appraisal 8(3), pp. 141-146.

Cole, D. 2015. The global uranium market. Reserve Bank of Australia.

Crowson, P. 2007. Uranium markets: somewhere over the rainbow? [In:] Proceedings of the 32nd International Symposium on Uranium and Nuclear Energy. Uranium Institute, London, UK, pp. 129-130.

Dittmar, M. 2013. The end of cheap uranium. Science of the Total Environment 461-462, pp. 792-798.

EURATOM 2013. Annual Report 2012. EURATOM Supply Agency. European Union.

Gabriel et al. 2013 - Gabriel, S., Baschwitz, A., Mathonničre, G., Eleouet, T. and Fizaine, F. 2013. A critical assessment of global uranium resources, including uranium in phosphate rocks, and the possible impact of uranium shortages on nuclear power fleets. Annals of Nuclear Energy 58, pp. 213-220.

Gawlik ed. 2013 - Gawlik, L., Grudziński, Z., Kamiński, J., Kaszyński, P., Kryzia, D., Lorenz, U., Mirowski, T., Mokrzycki, M., Olkuski, T., Ozga-Blaschke, U., Pluta, M., Sikora, A., Stala-Szlugaj, K., Suwała, W., Szurlej, A., Wyrwa, A. and Zyśk, J. 2013. Coal for Polish Energy sector in 2050 perspective - scenario analyses Górnicza Izba Przemysłowo-Handlowa, Katowice: Wyd. IGSMiE PAN, 299 p. (in Polish).

Geiger, A. 2011. Strategic Power Plant Investment Planning under Fuel and Carbon Price Uncertainty. Karlsruher Institut für Technologie (KIT), Karlsruhe.

Greenwood, J. 1981. Uranium supply and demand: the fifth annual symposium of the uranium institute, London, 2-4 September 1980. Energy Policy 9(2), pp. 170-171.

Hall, S. and Coleman, M. 2013. Critical analysis of world uranium resources. U.S. Scientific Investigations Report 2012-5239, 56 pp.

Hammond, G.P. 2000. Energy, environment and sustainable development: a UK perspective. Trans IChemE Part B: Process Safety and Environmental Protection 78(4), pp. 304-323.

IAEA 2001. Analysis of Uranium Supply to 2050. International Atomic Energy Agency. Vienna, 103 pp.

Jaśkowski, P. 2015. Methodology for enhancing reliability of predictive project schedules in construction. Maintenance and Reliability 17(3), pp. 470-479.

Johnson D. 1997. The triangular distribution as a proxy for beta distribution in risk analysis. The Statistician 46(3), pp. 387-398.

Kahouli, S. 2011a. Effects of technological learning and uranium price on nuclear cost: Preliminary insights from a multiple factors learning curve and uranium market modeling. Energy Economics 33, pp. 840-852.

Kahouli, S. 2011b. Re-examining uranium supply and demand: New insights. Energy Policy 39, pp. 358-376.

Layton, M. 2008. The global uranium outlook: is 2008/09 a buying opportunity? In: Proceedings of the 33th International Symposium on Uranium and Nuclear Energy. World Nuclear Association (WNA), London, UK, pp. $1-11$.

Maeda, H. 2005. The global nuclear fuel market-supply and demand: 2005-2030. In: Proceedings of the 30th International Symposium on Uranium and Nuclear Energy. Uranium Institute, London, UK, pp. 1-11.

Mays, W.M. 2005. Limitations to progress in developing uranium resources. In: Proceedings of the 30th International Symposium on Uranium and Nuclear Energy. World Nuclear Association (WNA), London, UK, pp. 39-60.

McMurray, J.M. 2005. The relationship between the uranium market price and supply-demand relationships. Proceedings of a technical meeting on Recent Developments in Uranium Exploration, Production and Environmental Issues organized by the IAEA in cooperation with the OECD Nuclear Energy Agency and 
DIAMO State Owned Enterprise held in Straz, Czech Republic, 6-8 September 2004; IAEA-TECDOC-1463, pp. 63-71.

Mercure, J.F. and Salas, P. 2012. An assessment of global energy resource economic potentials. Energy 46, 1, pp. 322-336.

Mercure, J. F. and Salas, P. 2013. On the global economic potentials and marginal costs of non-renewable resources and the price of energy commodities. Energy Policy 63, pp. 469-483.

Metal... 2013 - Metal Prospects: Uranium Market Outlook-Third Quarter 2013. RBC Capital Markets, 2013.

Mudd, G.M. 2014. The future of Yellowcake: A global assessment of uranium resources and mining. Science of the Total Environment 472, pp. 590-607.

NEA 2006. Forty Years of Uranium Resources, Production and Demand in Perspective. OECD, Nuclear Energy Agency, Paris.

Newcomb, R. and Reiber, M. 1984. The economics of coal and nuclear energy. In: Economics of the Mineral Industries: A Series of Articles by Specialists, fourth ed. AIMMPE, New York.

Nieć et al. 2012 - Nieć, M., Mucha, J., Sobczyk, E. and Wasilewska-Błaszczyk, M. 2012. The methodology of documenting mineral deposits. Part IV Estimating resources. Kraków: Wyd. IGSMiE PAN, 241 pp. (in Polish).

Nikolaus, A. 2014. Comparing recent uranium supply scenarios. IAEA Technical Meeting on the Nuclear Fuel Cycle Information System, 9-12 December 2014, Vienna, Austria.

Nuclear.. 2009 - Nuclear Fuel Cycle Information System: a Directory of Nuclear Fuel Cycle Facilities. 2009 Edition. International Atomic Energy Agency (IAEA), Vienna.

OECD/NEA 2008. Uranium 2007: Resources, Production and Demand. Red Book ed. OECD, Publishing NEAIAEA.

OECD/NEA 1987. Nuclear Energy and its Fuel Cycle: Prospects to 2025. Yellow Book ed. OECD, Publishing NEA-IAEA

OECD/NEA, 2015. Uranium 2014: Resources, Production and Demand. OECD, NEA.

Owen, A.D. 1984. An economic model of the US uranium market. Materials and Society 8, pp. 137-152.

Owen, A.D. 1985. The Economics of Uranium. Praeger, New York.

Patterson, J.A. 1970. World Uranium Supply and Demand. IAEA publishing, Paris, France.

PPEJ 2014. Program of the Polish Nuclear Energy (Program polskiej energetyki jądrowej). Accepted by Ministers Council on 24.06.2014. Warszaw (in Polish). [Online] Available at:

(http://www.mg.gov.pl/files/upload/19990/PPEJ_2014_01_28_po_RM.pdf) [Accessed: 3.03.2016].

Strategic... 2010 - Strategic Environmental Assessment for the central Namib Uranium Rush. Ministry of Mines and Energy, Windhoek, Republic of Namibiae.

UPA 2015 - UPA Report DOE Material Transfer Study. Uranium Producers of America (UPA) TradeTech.

Thomas, N, 1984. The International Uranium Market. Ballinger, New York.

Trieu et al. 1994 - Trieu, L.H., Savage, E. and Dwyer, G. 1994. A model for the world uranium market. Energy Policy 22(4), pp. 317-329.

Walczak, R. 2015. Selected methods of analysis and risk assessment. College of Economics and Social Sciences University of Warsaw, Plock, p. 125. (in Polish). 


\title{
PROGNOZOWANIE CENY URANU NA PODSTAWIE
}

KOSZTÓW EKSPLOATACJI ZŁÓŻ RUDY URANOWEJ

\author{
Słowa kluczowe
}

ceny uranu, popyt, podaż, złoża uranu, prognoza, metoda Monte Carlo

\section{Streszczenie}

W artykule przedstawiono koncepcję prognozowania cen uranu bazującą na kosztach eksploatacji rudy uranowej. Zbudowano model szacowania kosztów wydobycia surowca w czasie w zależności od wielkości podaży będącej odpowiedzią na popyt zgłaszany przez elektrownie jądrowe. Koszty te, przy sztywnym popycie na uran, determinują cenę tego surowca. Pozwala to szacować przyszłe ceny uranu na podstawie wiedzy o bazie zasobowej surowca oraz relacjach warunkujących zmianę parametrów opisujących zasoby. Szacunki takie obarczone są dużą niepewnością, dlatego w badaniach wykorzystano podejście stochastyczne, konstruując rozkłady prawdopodobieństwa wartości niepewnych parametrów. Na podstawie analizy literatury zidentyfikowano zmienne, których wartości są ze sobą skorelowane. W modelu zaimplementowano zidentyfikowane korelacje pomiędzy zmiennymi. Przyjęto szereg założeń dotyczących danych wejściowych, ograniczeń modelu i relacji między zmiennymi. Na podstawie symulacji modelu metodą Monte Carlo uzyskano rozkłady prawdopodobieństwa cen uranu w kolejnych latach aż do 2050 roku. Według uzyskanej prognozy ceny uranu do 2030 roku będą utrzymywały się na stałym poziomie wynoszącym około $90 \mathrm{USD} / \mathrm{kg}$ uranu. W kolejnych latach nastąpi wzrost cen, który z czasem będzie przybierał na sile. W 2050 roku oczekiwana wartość ceny uranu wyniesie około $130 \mathrm{USD} / \mathrm{kg}$ uranu.

\section{FORECASTING THE PRICE OF URANIUM BASED ON THE COSTS OF URANIUM DEPOSITS EXPLOITATION}

\author{
Keywords \\ uranium prices, demand, supply, uranium deposits, estimation, Monte Carlo method
}

\section{Abstract}

The paper presents the concept of forecasting uranium prices on the basis of the uranium deposits exploitation costs. The model for estimating the costs of raw material extraction over time, depending on the supply level sufficient to meet the demand from nuclear power plants, has been developed. The aforementioned costs, given the inelastic demand for uranium, determine the price of this raw material. This allows estimating the future price of uranium on the basis of knowledge of the resource base and the relationships determining changes in parameters characterizing the resources. As these estimates are affected by considerable uncertainty, the study has used a stochastic approach, constructing the precise probability distributions of uncertain parameters. Based on literature analysis, 
the variables that are correlated with each other have been identified. The model has implemented the identified correlations between variables. A number of assumptions regarding the input data, model limitations, and the relationship between the variables has been adopted. On the basis of the Monte Carlo simulation, the probability distribution of uranium prices in the coming years until 2050 has been obtained. According to the obtained estimation, uranium prices will remain stable at around $90 \mathrm{USD} / \mathrm{kg}$ by 2030 . The prices are expected to increase in the next years. It can be assumed that this trend will grow in the future. In 2050, the expected uranium price will be about $130 \mathrm{USD} / \mathrm{kg}$. 
